- RAM, REV. ADM. MACKENZIE, 17(2) • SÃO PAULO, SP • MAR./ABR. 2016 • ISSN 1518-6776 (impresso) • ISSN 1678-6971 (on-line) • http://dx.doi.org/10.1590/1678-69712016/administracao.v17n2p211-244. Submissão: 2 abr. 2015. Aceitação: 27 nov. 2015 Sistema de avaliação: às cegas dupla (double blind review). UNIVERSIDADE PRESBITERIANA MACKENZIE.

Silvio Popadiuk (Ed.), Thais Elaine Vick (Ed. Seção) p. 211-244.

\title{
PRODUCTION MANAGEMENT AND
}

\section{EMPLOYEES - A SURVEY OF AUTO PARTS COMPANIES $^{\mathrm{I}}$}

\section{LÍLIAN CARNEIRO SOUZA}

Mestra em Engenharia de Produção pelo Centro de Ciências Exatas e de Tecnologia da Universidade Federal de São Carlos (CCET-UFSCar). Professora adjunta do Departamento de Engenharia de Produção da Faculdade Anhanguera de Anápolis. Avenida Universitária, 683, Maracanã, Anápolis - GO - Brasil - CEP 75040-080 E-mail: lilian.carneiro@anhanguera.com

\section{ALESSANDRA RACHID}

Doutora em Engenharia de Manufatura e Materiais pela Faculdade de Engenharia Mecânica da Universidade Estadual de Campinas (Unicamp).

Professora associada do Centro de Ciências Exatas e de Tecnologia da Universidade Federal de São Carlos (CCET-UFSCar).

Rodovia Washington Luis, Km 235, Caixa Postal 676, Monjolinho, São Carlos - SP - Brasil - CEP 13565-905

E-mail: arachid@ufscar.br

I The authors thank the Fundação de Amparo à pesquisa do Estado de São Paulo (FAPESP). Grant \# 20II/18292-2.

Este artigo pode ser copiado, distribuído, exibido, transmitido ou adaptado desde que citados, de forma clara e explícita, o nome da revista, a edição, o ano e as páginas nas quais o artigo foi publicado originalmente, mas sem sugerir que a RAM endosse a reutilização do artigo. Esse termo de licenciamento deve ser explicitado para os casos de reutilização ou distribuição para terceiros. Não é permitido o uso para fins comerciais. 


\section{ABSTRACT}

Purpose: This paper presents an overview of the adoption of methods of production management methods for auto parts companies in Brazil and verifies if there is involvement of shop floor workers in their use, taking into consideration the relevance of involvement to organizational performance and obtaining the results expected from the adoption of these methods, as indicated by in line with research on participatory management and the manuals in the area of operations management.

Originality/gap/relevance/implications: Involvement is a significant construct in product management and has been widely researched, but little research has been dedicated to investigating whether there is any involvement of employees in the use of multiple methods. Most of the existing research concentrates analysis on the adoption of a single method in isolation and in the literature it has been observed that companies do not always follow the recommendation to involve workers in their use, thus what motivated this study.

Key methodological aspects: We conducted a survey in 95 auto parts companies to gain access to information about a wide range of auto parts companies, plotting an overview of the adopted production management methods adopted and examining the extent of the involvement of employees.

Summary of key results: Most of methods investigated were widely adopted by the companies surveyed. Generally, the surveyed companies stated that there is employee involvement, although this varies from one method to another. The study identified cases in which methods have been adopted and after some time have ceased to be used by some companies. The abandonment of Six Sigma occurred mainly in companies in which there was no involvement of employees in the application of this method. The method most commonly abandoned, however, was the suggestion program, despite exhibiting greater employee involvement, indicating that some companies continue to experience difficulty applying this type of method over time. Limited time for training may also have hampered the use of some methods. 
Key considerations/conclusions: The researched methods have been implemented by the examined companies. The research confirms that quality still plays a major role concerning employee involvement; representing one of the most noticeable aspects regarding lean production. Most of the investigated training is focused on this area, but the fact that time dedicated to training is short helps elucidate the difficulty related to involvement in methods which require a higher level of formal training. Cases in which companies implemented certain methods and soon discontinued them have been observed, highlighting the suggestion program, in which the employee involvement is central; what indicates that difficulties related to this involvement remain in some companies.

\section{KEYWORDS}

Production management. Workers' involvement. Management methods. Auto parts. Survey.

\section{INTRODUCTION}

Involvement is a significant theme in management and has been widely researched (Dundon, Wilkinson, Marchington, \& Ackers, 2004; Faria, 2009; Heller, 2003; Kalleberg, Nesheim, \& Olsen, 2009; Salerno, Zilbovicius, Arbix, \& Dias, I998; Smith, 2006; Vidal, 2007; Wilkinson, Donaghey, Dundon, \& Freeman, 20I4; Wood \& Wall, 2007). This is a key factor for success in the implementation of different management methods and leads to improvements in the performance of organizations (Butler, Tregaskis, \& Glover, 20II; Felstead, Gallie, Green, \& Zhou, 20ıо; Gonzalez, 20ıо; Helper \& Kleiner, 2008; Jones, Kalmi, \& Kauhanen, 20I0; Ogbeide \& Harrington, 20II; Olivella, Cuatrecasas, \& Gavilan, 2008; Richardson, Danford, Stewart, \& Pulignano, 20Iо; Tang, Chen, $\& \mathrm{Wu}$, 20Iо; Zu, Robbins, \& Fredendall, 20Iо).

Involvement, however, refers to a broad concept, mutable and difficult to define. It is used in different areas with different meanings and applied to diverse situations, even when the focus is on the shop floor workers (Donadone \& Grün, 200I; Dundon et al., 2004; Faria, 2009, Lawler, I986; Liboni, 200I). In this research, the involvement of workers in the use of methods of production management is the central issue.

Despite the relevance of the topic, little research can be found dedicated to investigating the involvement of employees on the shop floor in the use of 
multiple methods of production management (Helper \& Kleiner, 2008; Rachid, 2009; Vidal, 2007). Authors such as Andrietta and Miguel (2007), Cheng (2007), Pinto, Carvalho and Ho (2009), Schroeder, Linderman, Liedtke and Choo (2008), Tang et al. (20I0), and $\mathrm{Zu}$ et al. (2010) studied employee involvement in specific methods and observed signs that companies do not always follow the recommendation to involve workers in their use.

The automotive industry has been historically characterized as a pioneer in the development and dissemination of methods of production management. In particular, they have to adopt various methods to address the demands of automobile manufacturers (Rachid, Bresciani, \& Gitahy, 200I). The automotive industry production chain is regarded as strategic for industrial development and job creation, both in Brazil and in other developed and developing countries. Thus, it has been the subject of specific policies; in Brazil, these include the formation of industry chambers in the government of José Sarney (I985-1990), which persisted until the government of Fernando Henrique Cardoso (I995-2002), and various automotive policies, launched by this President and reissued under the following governments of Luiz Inácio Lula da Silva (2003-20II) and Dilma Rousseff (2OII-2OI4).

From the early I990s, the auto parts industry in Brazil went through a process of concentration and denationalization, significantly modifying their composition (Costa, I998; Salerno et al., I998; Sindicato Nacional da Indústria de Componentes para Veículos Automotores [Sindipeças], 20I2; Souza \& Rachid, 20I4). These changes also influenced the organization of productive units and led to the adoption of new methods of production management, many of which are of direct interest to this research.

The purpose of the paper is to provide an overview of the adoption of production management methods by auto parts companies and the involvement of shop floor workers in their use. The definition of this goal considers the relevance of involvement for organizational performance and obteained the results expected from the adoption of these methods. Moreover, it considers that most of the research identified in the literature review concentrates its analysis on the adoption of only one method in isolation.

This paper is the result of a survey that investigated different methods of production management adopted by companies producing auto parts and whether shop floor workers are involved in their use. The paper proceeds as follows. The next section presents the concept of involvement used in this research. Section 3 shows changes in involvement over time, according to different models. Section 4 discusses the auto parts industry, the relationship with automakers, and how this relationship has led to changes in production management. In section 5 , we describe the procedures for the survey. Section 6 presents the results of the 
survey of auto parts companies, highlighting data concerning the adoption of methods of production management, their use, and the involvement of employees.

\section{CONCEPTUALIZING INVOLVEMENT}

The term "involvement" is difficult to define and changes according to time and place, as appropriate for different players in different positions (Donadone \& Grün, 200I; Dundon et al., 2004; Faria, 2009; Lawler, I986; Liboni, 200I; Smith, 2006). Researchers focusing on this topic use different terms to approach it, reflecting the breadth of interpretations. Richardson et al. (2010) use "participation and involvement". Vidal (2007) terms it broad involvement or empowerment. Dias and Zilbovicius (2009) use empowerment. Heller (1998, 2003) uses organizational democracy, in which the influence on decisions will be more extensive.

Faria (2009) points to the existence of different so-called participatory models: self-management, in which all employees participate in administrative decisions; the cooperative movement, in which all members are also members of the cooperative; participatory management, which seeks the manifestation, in an organized manner, of employees, customers, suppliers, and other stakeholders in the process of administration of the company.

In this paper, we use a clearly defined concept with the aim of reducing differences in interpretation during the research process. The used concept of involvement considers the involvement of workers in the use of production management methods. This concept fits the definitions used by some authors in research on the topic, as in the case of participatory management as classified by de Faria (2009). This is also the case in participatory arrangements which aim to contribute to management, leading to improvements in efficiency and productivity, as shown by Dundon et al. (2004). These authors point out three other forms of expression of workers: voice, which is the individual manifestation of dissatisfaction in relation to a specific problem with management; representative participation, through collective organization to offset the power of management; and partnerships of mutual interest between the company and its employees, aiming to ensure the company's long-term viability.

Wood and Wall (2007) discuss the possibility of stating opinions through suggestions for improvement, namely, the voice of workers, a concept that fits the definition of this paper. According to these authors, such voice would also involve means of dealing with grievance and bargaining, and participation in the strategic decisions of the organization. 
Lawler, Mohrman and Ledford (I992) propose a model of high involvement, which takes two distinct forms: participation in the broader decisions of the company and the ability to make decisions related to the work itself, which is related to the definition of involvement used here. In this case, the model proposes that the work organization is based on encouraging greater flexibility, proactivity behavior, and collaboration, through intensive training, expanding the ability of the workers to engage, work as a team, develop multiple tasks, express their ideas and exchange information.

There is also a close link with the concept of subjective engagement, as expressed by Zarifian (2009), which considers the opportunities for expression, action, and cooperation among workers in order to generate greater organizational efficiency and improvements in productivity. The definition of this study coincides with what Atkinson and Meager (1986), Smith (1997), and Wood (I989) call functional flexibility of work, also called qualitative or internal flexibility, which is the extension of the set of activities performed by employees.

The concept used is inspired by the recommendations of the different methods of production management, especially those linked to lean production, which highlight the importance of involving workers in their use to obtain the results expected from their deployment.

\section{CHANGES IN THE WAY OF INVOLVEMENT}

The involvement of workers in production has varied greatly over time. In craft production, the craftsman was involved from the conception of the product and the work organization until the sale of the finished product. With the advent of the first factories and the division of labor in manufacture, this involvement decreased significantly, being restricted to the accomplishment of individual tasks. Such tasks were simplified and emptied of meaning to an even greater extent with the organizational methods of work following the Taylor and Ford models, seeking to make work as simple as possible (Coriat, I985, I988; Ford, I925; Larangeira, I997; Marx, I997; Womack, Jones, \& Roos, I992).

In the late twentieth century, there were alternative production models to Taylorism - Fordism. One of the most advanced models in terms of job enrichment and autonomy at work was established on the basis of the principles of the sociotechnical system, developed by the Tavistock Institute. According to these principles, it is necessary to jointly consider the technical and social aspects of work organization. Based on these principles, semi-autonomous groups were implemented on the assembly lines of vehicles for Volvo and Saab Scania in 
Sweden in the I970s and I980s (Cherns, I976; Ferreira, Hirata, Marx, \& Salerno, I99I). These experiences, however, had limited dissemination (Batt \& Doellgast, 2004; Edwards, Geary, \& Sisson, 2002; Heller, I998; Kalleber et al. 2009).

In the late I970s, the notion of lean production over took the Taylor and Ford models in the organization of production. This model, based on techniques and methods applied by Japanese industries since I950, was released by the Massachusetts Institute of Technology (MIT) to the West as a solution to problems of organization in production and involved changes in the work organization (Womack et al., I992). Implementation of the model would lead to greater commitment on the part of the workers, who were to play different roles, including those related to quality control and inventory levels, as well as maintenance. Moreover, they would be able to operate different equipment, in addition to suggesting improvements (Gerwin, I987).

Research on the implementation of lean production in the I980s and I990s confirms an breakthrough in the involvement of employees in the management of production, mostly linked to quality. The different methods employed to control and improve quality present in the lean production model had a strong role in the diffusion of ideas associated with participation, and that remained with the adoption of ISO 9000 (Donadone \& Grün, 200I; Fleury \& Humphrey, I992; Rachid, I996, 2009; Wood \& Wall, 2007).

Despite just-in-time be appointed to one of the main methods of lean production, there are surveys that indicate its limited application in Brazil. Often, what happens is the transfer of stock to suppliers, as noted by Alves et al. (2003) in the automotive industry. The Lean Institute (20IIa, 20IIb) has itself pointed out difficulties in the "operation and support of the system pulled. This occurs for various reasons, causing it to lose the gains of involvement and involvement of the people".

ISO 9000, a standard widely applied, also focuses on the aspect of quality. This certification process requires that all employees whose work has an impact on quality should receive training in the standard. This has led companies, even smaller firms, to invest in training as any worker can be questioned about the firm's procedures during audits (Quazi \& Jacobs, 2004; Rachid, 2007). The automotive industries indifferent countries have generated adaptations of ISO 9000 , with additional requirements for their suppliers of auto parts, as in the standards listed below:

- Quality System (QS) of EUA;

- Verband der Automobilindustrie - VDA (automotive industry association) in Germany; 
- Evaluation de l'Aptitude Qualité Fournisseur - EAQF (evaluation of the capacity of the supplier in terms of quality) in France;

- Associazone Nazionale Fra Industrie Automobilistiche - Anfia (Valutazione di Sistemi Qualità - AVSQ) in Italy;

- ISO/TS I6949 and Technical Specification (TS), an international ISO 900I adaptation, the result of an agreement between the automotive industry associations of certain countries (Rachid, Sacomano, Bento, Donadone, \& Alves, 2006, p. I9I).

These certifications are very widespread in the auto parts industry. Table I shows that among the 504 Sindipeças member companies in 2010 there were 850 certificates, i.e., an average of I. 68 per company. The number of certificates varies among companies, but the spread has been growing, and these encompass small and medium-sized companies in the supply chain. According to Rachid, et al. (2006), this is either due to the requirements of customers, usually large auto parts companies, or due to imitation of models of other companies in the sector.

\section{TABLE I}

AUTO PARTS COMPANIES CERTIFIED OR IN THE PROCESS OF CERTIFICATION (BRAZIL, 2OIO)

\begin{tabular}{lcccc}
\hline STANDARD & CERTIFICATES & $\%$ & IN CERTIFICATION & $\%$ \\
\hline ISO TS 16949 (2002 and 2009) & 329 & 38.7 & 24 & 32.4 \\
\hline ISO 9001 (2000 and 2009) & 291 & 34.2 & 9 & 12.2 \\
\hline ISO 14001: 2004 & 205 & 24.1 & 40 & 54.1 \\
\hline VDA 6.1 / 6.3 & 19 & 2.2 & 1 & 1.4 \\
\hline AVSQ & 3 & 0.4 & 0 & 0.0 \\
\hline EAQF & 3 & 0.4 & 0 & 0.0 \\
\hline Total & 850 & 100.0 & 74 & 100.0 \\
\hline
\end{tabular}

Source: Sindipeças (20II).

The same progress has not been observed in relation to other management methods, as in the case of quality circles (QCs), which are meetings in which employees discuss issues related to their work and propose improvements. This was one of the first methods disseminated in Western countries, but most QCs were discontinued after a few years (Hill, I991; Salerno, I985). Also, according to 
Hill (I99I), this occurred because the work organization and the organizational structure of the companies remained unchanged, and the management was not prepared to respond to initiatives from the bottom up.

Working groups also have not advanced to any great extent either. Despite the fact that semi-autonomous groups and the socio-technical assumptions continue to be an important reference in the field of work organization, their diffusion has been somewhat restricted. In the most widespread group approaches, such as the groups observed in Japanese companies, each worker must operate different equipment, but workers have less autonomy and their tasks are less complex (Kalleberg et al., 2009; Marx, 1997). Even more common is the rotation of workers between different individual work stations within the same area or even between different areas of manufacturing (Friedrich, Kabst, Weber, \& Rodehuth, I998; Rachid, 2009; Vidal, 2007).

The allocation of a greater variety of activities to workers has contributed to change the criteria for their selection, with greater demands for formal schooling, and investment in courses and training. This has led to an increase in the percentage of workers who have completed high school and the reduction of those with less schooling in various activities (Invernizzi, 2000; Perticarrari, 2003; Rachid et al., 2006).

More recent research, however, has shown the limited extent of employee involvement in the use of management methods and even a loss of emphasis over the years (Moriones, Pintado, \& Merino, 2010; Rachid, 2009; Vidal, 2007; Wood \& Wall, 2007). Pinto et al. (2009) observed the limited extent of employee involvement in firms applying Six Sigma. The same was observed by Marx (I997), Schroeder et al. (2008), and Araújo and Rentes (2006) in research on the kaizen approach, and Pyzdek (2003) and Vidal (2007) in research on lean production.

A relatively recent quality management method is Six Sigma. This involves the creation of teams to work on improvement projects and has a strong emphasis on the prevention of defects through the use of a package of statistical techniques. Different authors have pointed out that the participation of employees is an important factor for its success (Andrietta \& Miguel, 2007; Cheng, 2007; Iwaarden, Wielea, Daleb, Williams, \& Bertsch, 2008; Fulton, 2003; Ponticel, 2004). Nevertheless, a number of studies have found this participation to be very limited (Pinto et al., 2009; Rachid, 2009; Smith, 2003).

The research that gave rise to this paper evaluated the adoption of selected methods in auto parts companies. Before presenting the results of the survey, we provide a brief presentation of the main changes observed in this sector over past decades. 


\section{THE AUTO PARTS INDUSTRY}

The automotive industry was the scene of creation of lean production and was among the pioneers of its adoption in the West, driven mainly by the competitive threat posed by Japanese vehicles. In addition to the management methods presented in the previous section, this model led to changes in the relationship between automakers and the suppliers of auto parts. According to Womack et al. (1992), in Japan, there is cooperation between customers and suppliers, with lasting relationships, joint development projects, and the integration of methodologies and processes. Efforts at reducing costs and continuous improvement projects go beyond the borders of the company and involve the suppliers, that performing just-in-time deliveries based on the demand of the client company, possibly more than once per day (Slack, Chambers, \& Johnston, 2002).

Such relationships went on to influence vehicle assemblers in Western countries. According to Santos and Pinhão (2000), these firms reorganized the purchasing process and created specialized areas in the selection and development of suppliers. This process was accompanied by greatly increased outsourcing, and a requirement imposed by automobile manufacturers for automotive companies to adopt different methods of lean production (Costa, I998; Santos \& Pinhão, 2000).

Automobile manufacturers also sought to identify key suppliers, consolidated as first-tier suppliers. These are involved in the development of vehicles from the start of the project, and should generally establish productive units in all the locations where that vehicle is produced, in what is termed "follow sourcing" (Santos \& Pinhão, 2000). This strategy is most common for components that are difficult to manufacture and those for which the cost of storage is high. For minor components, automobile manufacturers often adopt a global sourcing strategy, seeking suppliers that meet their requirements in terms of quality and obtaining the lowest price through global quotes (Costa, I998).

The requirements imposed by automakers led to the emergence of mega suppliers who have global basis and have become barriers to the entrance of national auto parts companies in Brazil (Carvalho, Queiroz, Consoni, Costa, \& Costa, I997). Most are not framed as first-tier suppliers, being relegated to the second tier or acquired by global companies, starting a process of concentration and denationalization in auto parts (Costa, I998; Salerno et al., I998).

Despite the growth of the automobile industry in the last decade, some of the demand for components began to be imported, mainly from Asian countries, and thus the trade balance of the sector showed signs of deficit in 1997 (Sindipeças, 20I2). The adoption of techniques of lean manufacturing and the 
growth in global competition have had an impact on the productivity of industry and employment. The evolution of employment in this industry can be seen in Graph I. In I994, there were 236,600 jobs, decreasing to 167,000 in 1998 , and remaining close to that level until 2003. From then on, employment in the industry has fluctuated, but has never returned to the level of I994. In 2013, there were 220,000 jobs.

\section{GRAPH I}

EMPLOYMENT IN THE AUTO PARTS SECTOR (I994 TO 20I3, THOUSANDS)

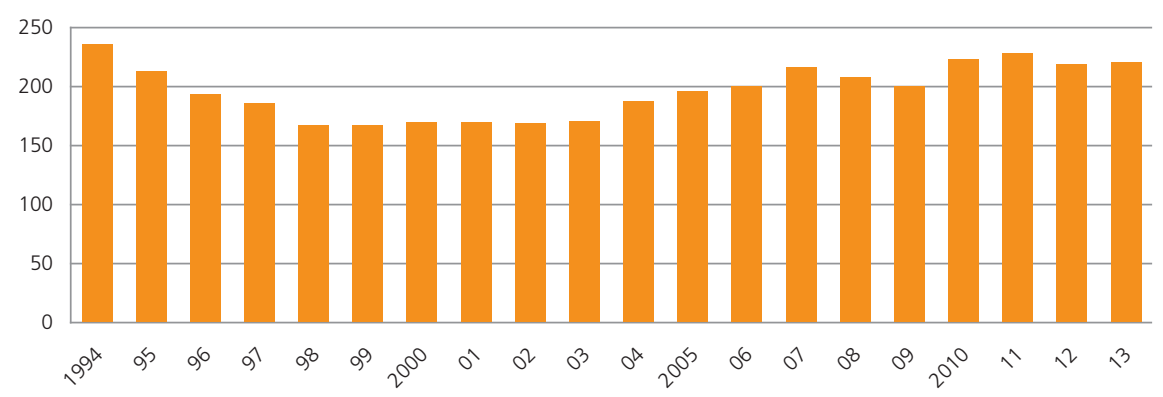

Source: Sindipeças (20I4).

Revenues per employee, however, went from US\$ 60,000 to US\$99,000 between I994 and 2004 and from US\$ I28,000 in 2005 to US\$237,000 in 20II, as can be seen in Graph 2, representing a significant increase, even taking into account the devaluation of the dollar against the real between 2006 and 2013 .

\section{GRAPH 2}

REVENUE PER EMPLOYEE (I994 TO 20I3, US\$ THOUSANDS)

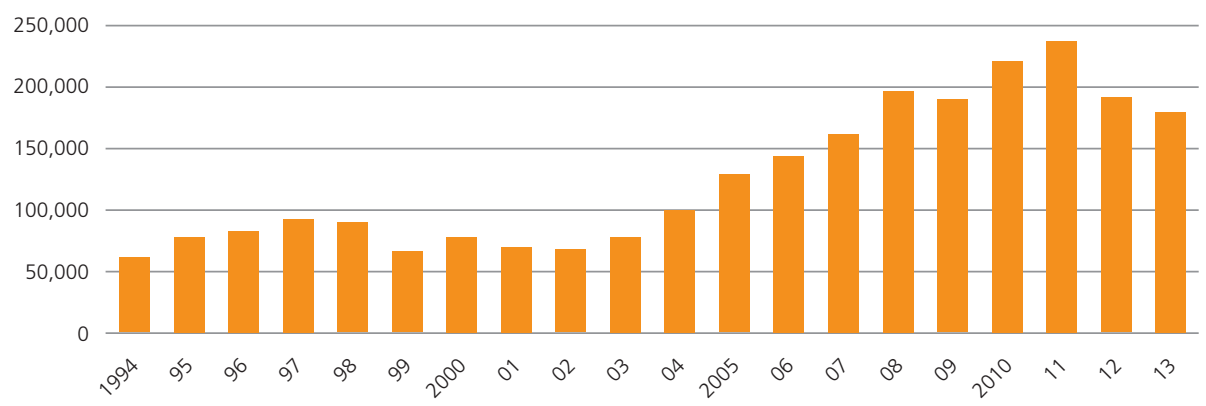


With the resumption of growth in the sector after I993, productivity increased, and the number of employees continued to decline or remain at the same level until 2003, after which it again grew, but without reverting to the I990 level.

\section{RESEARCH PROCEDURES}

We conducted a survey, the goal of which was to gain access to information concerning a wide range of auto parts companies, develop an overview of the adopted production management methods adopted, and establish the extent of employee involvement. The survey employed a structured questionnaire, using as a basis for the items the literature review and questionnaires used in our own previous own research on the work organization, mainly in the automotive and white goods industry (Alves et al., 2003; Araújo, Gitahy, Rachid, \& Cunha, 2006; Moriones et al., 20I0; Nichols \& Cam, 2005; Rachid, 2009; Vidal, 2007; Wood $\&$ Wall, 2007).

The questions were grouped into four blocks:

- Characterization of the company, products, and customers.

- The management methods deployed, in what year, which were still in use, and in which there was the involvement of employees.

- Tasks related to quality and maintenance, and the operation of different equipment by workers.

- Training on the methods offered to workers and its duration.

The questionnaire was tested with 2I people working in other sectors, after which minor adjustments were made on the basis of their comments and the difficulties observed during completion.

To select the companies for the sample in the main study, we used firms associated with Sindipeças. We selected those firms that had automotive components among their products, excluding any with non-automotive products, such as automakers also associated, consulting firms, and importers. To identify the main customers of the companies in the automotive industry and confirm their participation in the survey, we consulted the pages of companies on the internet, identifying a total of $50 \mathrm{I}$ as auto parts companies.

We made initial contact by telephone to explain the purpose of the survey and identify the person who could complete the questionnaire with the necessary information. For some companies, it was not possible to make contact by 
telephone and/or email. For others, it was not possible to identify a professional able to respond to the questionnaire, and yet others refused to participate in the research. Thus, the questionnaire was sent to 388 companies, of which 95 returned the completed version.

Within the automotive sector, the quality area was chosen as the first option as most closely related to the use of researched management methods. Thus, most of the respondents are from this area, as can it be seen in Table 2, showing the areas of operation and positions of respondents.

\section{TABLE 2}

\section{AREAS AND POSITIONS OF THE RESPONDENTS}

\begin{tabular}{|c|c|c|c|}
\hline AREA & $\begin{array}{l}\text { NUMBER OF } \\
\text { RESPONDENTS }\end{array}$ & POSITION & $\begin{array}{l}\text { NUMBER OF } \\
\text { RESPONDENTS }\end{array}$ \\
\hline \multirow{11}{*}{ Quality } & \multirow{11}{*}{79} & Manager & 20 \\
\hline & & Coordinator & 16 \\
\hline & & Supervisor & 14 \\
\hline & & Analyst & 12 \\
\hline & & Assistant & 6 \\
\hline & & Engineer & 3 \\
\hline & & Technician & 3 \\
\hline & & Inspector & 2 \\
\hline & & Director & 1 \\
\hline & & Specialist & 1 \\
\hline & & Consultant & 1 \\
\hline \multirow{3}{*}{ Industry/production } & \multirow{3}{*}{8} & Manager & 6 \\
\hline & & Chief & 1 \\
\hline & & Coordinator of PCP & 1 \\
\hline
\end{tabular}

(continue) 
TABle 2 (CONCLUSION)

AREAS AND POSITIONS OF THE RESPONDENTS

\begin{tabular}{llll}
\hline \multirow{2}{*}{ AREA } & $\begin{array}{c}\text { NUMBER OF } \\
\text { RESPONDENTS }\end{array}$ & POSITION & NUMBER OF \\
& & RESPONDENTS \\
\cline { 3 - 4 } Engineering & 4 & Supervisor & 1 \\
\cline { 3 - 4 } & & Engineer & 1 \\
\cline { 3 - 4 } Company & 3 & Analyst & 1 \\
\cline { 3 - 4 } & & Manager & 1 \\
\hline Commercial & 1 & Secretary & 1 \\
\hline
\end{tabular}

Source: Elaborated by the authors.

\section{RESULTS}

This section presents the results of research on the adoption and use of methods of production management in the 95 auto parts companies surveyed, as well as the involvement of employees. All the 95 companies are located in the south or southeast, where 99.1\% of the companies associated with Sindipeças (20II) are concentrated. Most companies have 60 to 500 employees, and these firms also have the greatest representation in terms of affiliation with Sindipeças, as can be observed in Table 3. The surveyed companies occupy different positions in the automotive chain, providing parts to automakers, to other auto parts companies, and/or to the aftermarket.

\section{TABLE 3}

SIZE OF COMPANIES SURVEYED

\begin{tabular}{lccc}
\hline NUMBER OF EMPLOYEES & $\begin{array}{c}\text { ASSOCIATED TO } \\
\text { SINDIPEÇAS (\%) }\end{array}$ & SURVEYED & $\%$ \\
\hline $1-30$ & $5.4 \%$ & - & - \\
\hline $31-60$ & $8.4 \%$ & 5 & $5.3 \%$ \\
\hline
\end{tabular}

(continue) 
TABLE 3 (CONCLUSION)

SIZE OF COMPANIES SURVEYED

\begin{tabular}{lccc}
\hline NUMBER OF EMPLOYEES & $\begin{array}{c}\text { ASSOCIATED TO } \\
\text { SINDIPEÇAS }(\%)\end{array}$ & SURVEYED & $\%$ \\
\hline $61-125$ & $17.9 \%$ & 18 & $18.9 \%$ \\
\hline $126-250$ & $20.3 \%$ & 19 & $20.0 \%$ \\
\hline $251-500$ & $20.7 \%$ & 26 & $27.4 \%$ \\
\hline $501-1000$ & $12.4 \%$ & 9 & $9.5 \%$ \\
\hline $1001-2000$ & $9.0 \%$ & 7 & $7.4 \%$ \\
\hline $2001-4000$ & $4.0 \%$ & 5 & $5.3 \%$ \\
\hline$>4000$ & $1.8 \%$ & 5 & $5.3 \%$ \\
\hline No response & - & 1 & $1.1 \%$ \\
\hline Total & $100.0 \%$ & 95 & $100.0 \%$ \\
\hline
\end{tabular}

Source: Elaborated from Sindipeças (20II) and own research.

We sought to identify which management methods were adopted by the companies in the sample, if they still used them, and whether their employees were involved in their use. To this end, the questionnaire presented a list of management methods identified in the literature review and our own prior research, namely:

- Suggestion programs.

- Troubleshooting groups.

- Preventive maintenance.

- Just-in-time/Kanban.

- Total Quality.

- Six Sigma.

- ISO 9000.

- $\quad$ ISO I4000.

Table 4 presents the number of companies that had adopted each of these methods. There was also space on the questionnaire for respondents to add other relevant methods adopted. Among those most cited, three specific standards 
for the automobile industry were mentioned, ISO TS I6949, the QSB, and the VDA, and these have been included in the table. In addition, the companies cited another 30 management methods (see Appendix A). Among the methods presented in the questionnaire, the ISO I4000 standard, Total Quality, and Six Sigma methods were less cited, having been adopted by less than half of the companies surveyed.

TABLE 4

ADOPTION OF METHODS OF PRODUCTION

MANAGEMENT IN THE COMPANIES SURVEYED

\begin{tabular}{lcc}
\hline METHOD & ADOPTION & $\begin{array}{c}\% \text { COMPANIES } \\
(n=95)\end{array}$ \\
\hline Preventive maintenance & 86 & 90.5 \\
\hline Troubleshooting groups & 80 & 84.2 \\
\hline ISO 9000 & 80 & 84.2 \\
\hline Suggestion programs & 76 & 80.0 \\
\hline ISO TS16949 & 63 & 66.3 \\
\hline Just-in-time/Kanban & 60 & 63.2 \\
\hline ISO 14000 & 48 & 50.5 \\
\hline Total Quality & 45 & 47.4 \\
\hline Six Sigma & 26 & 27.4 \\
\hline QSB & 14 & 14.7 \\
\hline VDA & 10 & 10.5 \\
\hline
\end{tabular}

Source: Elaborated by the authors.

Graph 3 shows the year of adoption of each method, highlighting the most common year for companies that provided this information. It can be observed that the adoption of methods before 2000 was barely mentioned and there was only one case of adoption in the year I980, ISO 9000. 


\section{GRAPH 3}

\section{YEAR OF ADOPTION OF METHODS}

\section{Preventive maintenance}

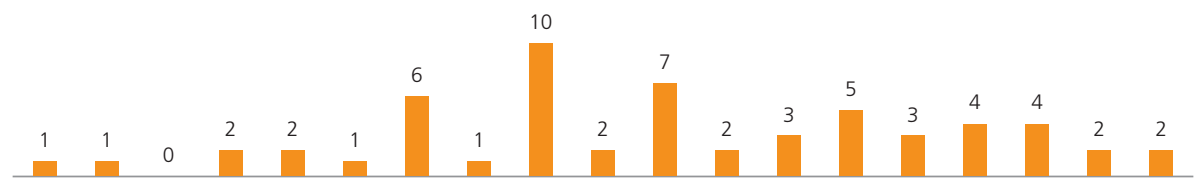

1992199319941995199619971998199920002001200220032004200520062007200820092010

\section{Troubleshooting groups}

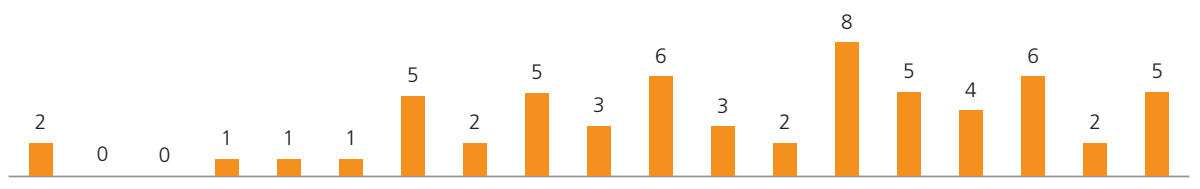

1992199319941995199619971998199920002001200220032004200520062007200820092010

ISO 9000

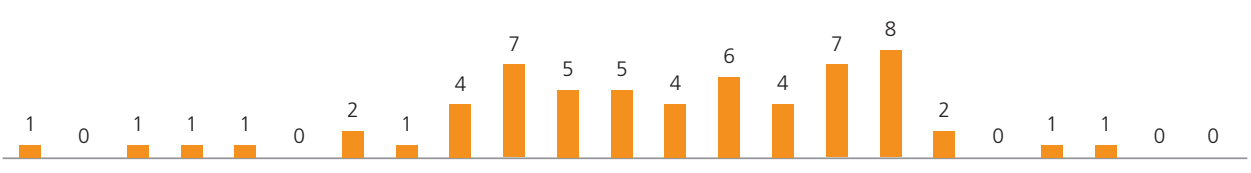

19871990199119921993199419951996199719981999200020012002200320042005200620072008200920102011

\section{Suggestion programs}

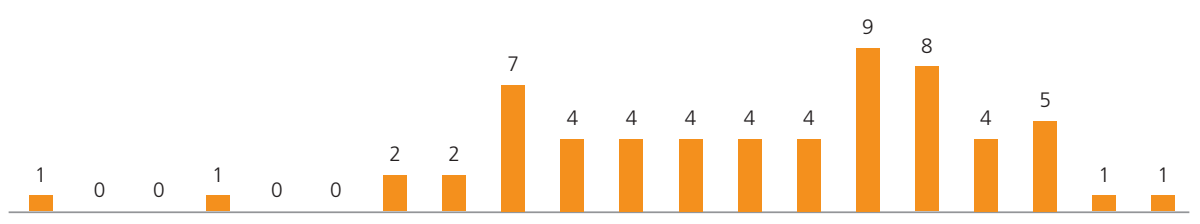

19921993199419951996199719981999200020012002200320042005200620072008200920102011

(continue) 
GRAPH 3 (CONCLUSION)

YEAR OF ADOPTION OF METHODS

Normal ISO TS16949

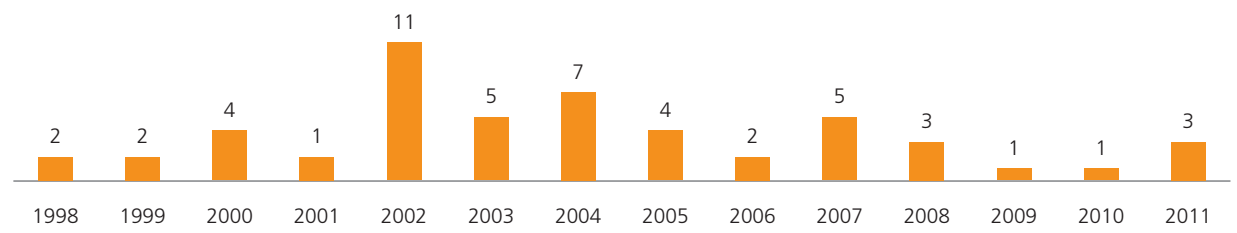

Just-in-time/Kanban

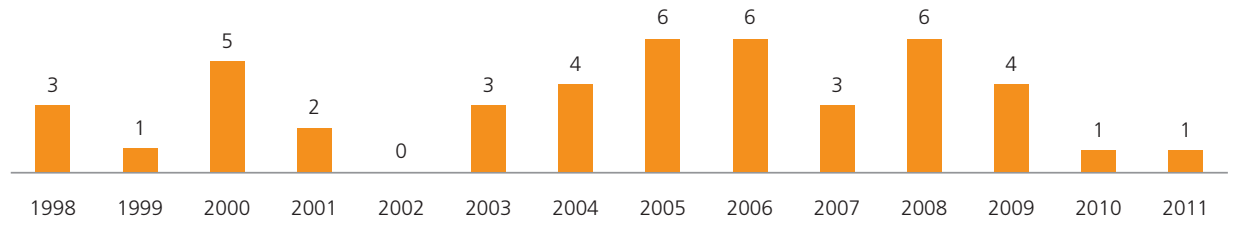

ISO 14000

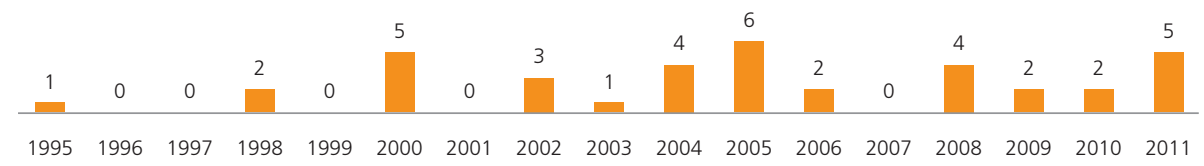

Total quality

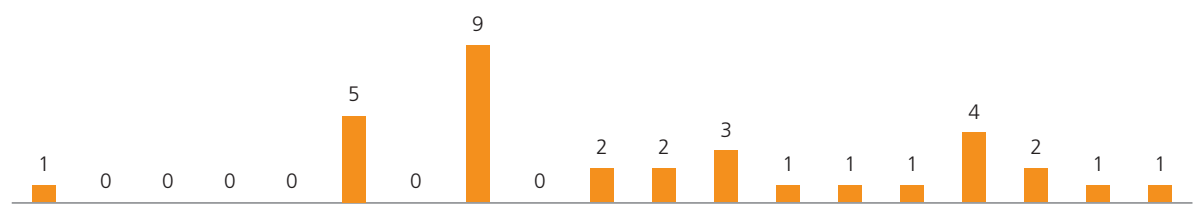

$1993199419951996199719981999200020012002 \quad 200320042005200620072008200920102011$

\section{Six Sigma}

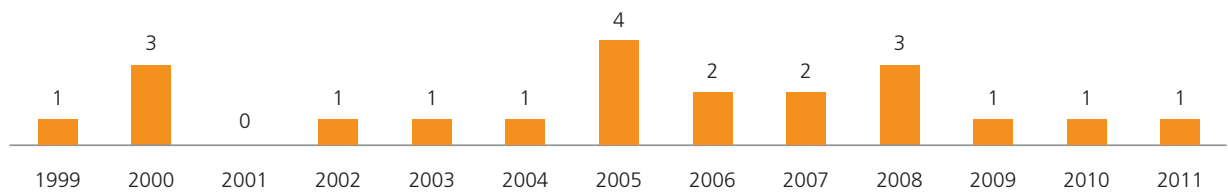

Source: Elaborated by the authors. 
Graph 4 shows the total number of methods adopted by year in the companies surveyed. It can be observed that there is a large concentration of responses for 2000 , with 52 adoptions, and in 2005 , with 4I, which gives the impression that some of the respondents reported the approximate year.

\section{GRAPH 4}

TOTAL NUMBER OF METHODS ADOPTED BY YEAR

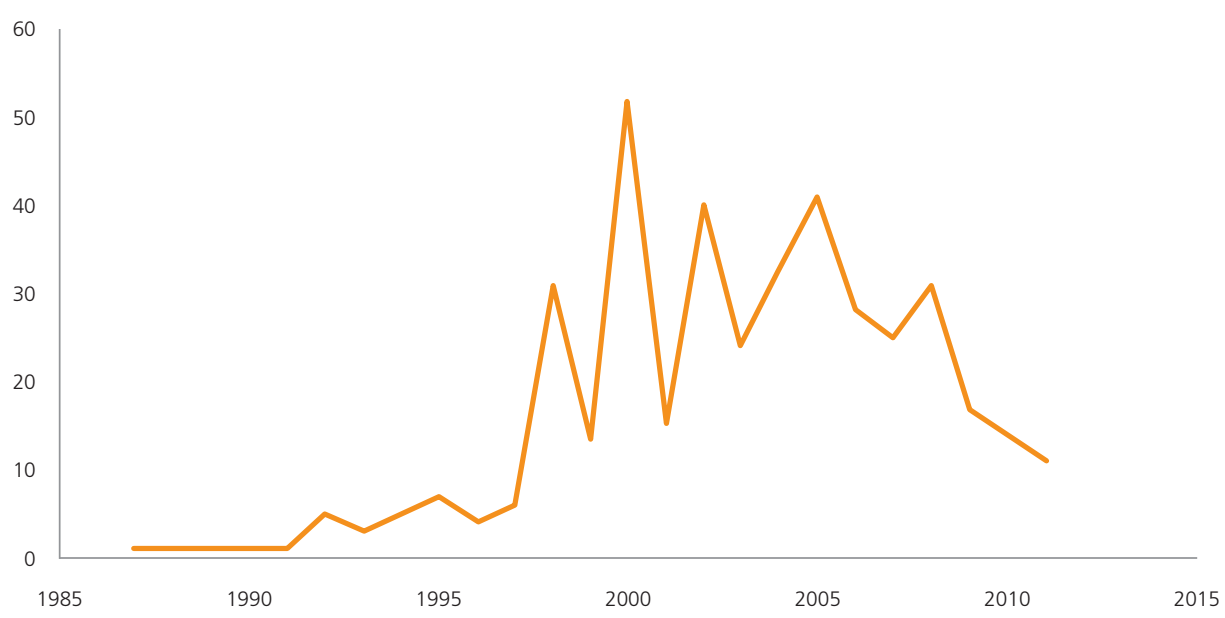

Source: Elaborated by the authors.

Despite this limitation, it is possible to identify methods widespread earlier, such as ISO 9000, preventive maintenance, troubleshooting groups, suggestion programs, and Total Quality. The most recently adopted methods are just-intime/Kanban, ISO I4000, Six Sigma, and ISO TS I6494.

Table 5 shows the number of companies reporting the involvement of workers in the use of the methods. The responses point to a large involvement in more than $80 \%$ of the companies surveyed, and in the use of most of the methods. These data indicate that, in most cases, the companies followed the recommendation of manuals to involve workers in the use of the methods. Employee involvement is lower for just-in-time/Kanban and Six Sigma, i.e., those methods adopted more recently by the companies surveyed. In the case of Six Sigma, employee involvement is significantly lower, confirming a trend observed by Pinto et al. (2009), Rachid (2009), and Smith (2003). 
TABLE 5

EMPLOYEE INVOLVEMENT IN THE USE OF THE METHODS

\begin{tabular}{lccc}
\hline METHOD & ADOPTION & INVOLVEMENT & $\%$ \\
\hline Suggestion programs & 76 & 76 & 100.0 \\
\hline Total Quality & 45 & 44 & 97.8 \\
\hline ISO 9000 & 80 & 78 & 97.5 \\
\hline ISO 14000 & 48 & 46 & 95.8 \\
\hline ISO TS16949 & 63 & 60 & 95.2 \\
\hline Troubleshooting groups & 80 & 73 & 91.3 \\
\hline Preventive maintenance & 86 & 76 & 88.4 \\
\hline Just-in-time/Kanban & 60 & 50 & 83.3 \\
\hline Six Sigma & 26 & 15 & 57.7 \\
\hline
\end{tabular}

Source: Elaborated by the authors.

The companies surveyed were also asked if they were still using the methods as previous research has shown cases of companies that have adopted a certain management method, but then ceased using it. Table 6 shows the number of companies that adopted each method and those methods no longer in use, and Table 7 presents the involvement of workers in the use of discontinued methods.

\section{TABLE 6}

\section{METHODS NO LONGER USED}

\begin{tabular}{lccc}
\hline METHOD & ADOPTION & NO LONGER IN USE & $\%$ \\
\hline Suggestion programs & 76 & 20 & 26.3 \\
\hline Six Sigma & 26 & 5 & 19.2 \\
\hline Just-in-time/Kanban & 60 & 8 & 13.3 \\
\hline ISO 9000 & 80 & 8 & 10.0 \\
\hline Troubleshooting groups & 80 & 4 & 5.0 \\
\hline Preventive maintenance & 86 & 4 & 4.7 \\
\hline
\end{tabular}


TABLE 6 (CONCLUSION)

METHODS NO LONGER USED

\begin{tabular}{lccc}
\hline METHOD & ADOPTION & NO LONGER IN USE & $\%$ \\
\hline Total Quality & 45 & 2 & 4.4 \\
\hline ISO 14000 & 48 & 2 & 4.2 \\
\hline ISO TS16949 & 63 & 0 & 0.0 \\
\hline
\end{tabular}

Source: Elaborated by the authors.

The method with the highest discontinuity was the suggestion programs, although it was the only method in which there is (or was) the involvement of employees in all companies surveyed. Therefore, difficulties in maintaining this kind of method persist, as noted in previous decades in research on a method with similar purposes, the QCs (Hill, I99I). In the case of Six Sigma, among the five cases of companies that have stopped using it, four did not involve workers. This may indicate that the lack of involvement is related to it being abandoned.

In relation to just-in-time, however, the problem was not lack of employee involvement as of the eight companies that ceased using it, seven involved employees. In this case, the difficulty in deployment appears to be related to other aspects, as pointed out by Alves et al. (2003) and the Lean Institute (201ra, 2OIIb).

\section{TABLE 7}

\section{METHODS NO LONGER USED AND EMPLOYEE INVOLVEMENT}

\begin{tabular}{lccc}
\hline METHOD & NO LONGER USED & EMPLOYEE INVOLVEMENT & $\%$ \\
\hline Suggestion programs & 20 & 20 & 100.0 \\
\hline Just-in-time/Kanban & 8 & 7 & 87.5 \\
\hline ISO 9000 & 8 & 7 & 87.5 \\
\hline Six Sigma & 5 & 1 & 20.0 \\
\hline Troubleshooting groups & 4 & 3 & 75.0 \\
\hline Preventive maintenance & 4 & 2 & 50.0 \\
\hline Total Quality & 2 & 2 & 100.0 \\
\hline
\end{tabular}


TABLE 7 (CONCLUSION)

METHODS NO LONGER USED AND EMPLOYEE INVOLVEMENT

\begin{tabular}{lccc}
\hline METHOD & NO LONGER USED & EMPLOYEE INVOLVEMENT & $\%$ \\
\hline ISO 14000 & 2 & 1 & 50.0 \\
\hline ISO TS16949 & 0 & -- & -- \\
\hline
\end{tabular}

Source: Elaborated by the authors.

In eight companies, respondents said they stopped using the ISO 9000 standard. It is noteworthy, however, that six of these companies have adopted the use the of ISO TSi6949 standard and therefore remain in compliance with the requirements of ISO. In other cases, the number of occurrences of use is even smaller, not allowing broader conclusions about the relationship between discontinuing the method and employee involvement.

In the case of ISO TSi6949, in addition to incorporating a large number of voluntary terms (63), no company stopped to use it, which reinforces the information provided by Sindipeças (20II) about the wide dissemination of the standard. Preventive maintenance and troubleshooting groups also demonstrate wide use. Total Quality, although not adopted by many companies, continues to be used by them. The ISO I4000 standard has few applications compared to other standards, but only a few companies have stopped using it, which reinforces the information provided by Sindipeças (2OII) that this certification is growing in the auto parts sector.

We also investigated if shop floor workers operate different machines or perform different operations, and whether they participate in maintenance and quality control activities. In this case, the objective was to verify whether or not they are involved with these activities, even without using a method of quality management in particular. The responses are shown in Table 8.

\section{TABLE 8}

EMPLOYEE INVOLVEMENT IN DIFFERENT ACTIVITIES

\begin{tabular}{lcc}
\hline ACTIVITY & NUMBER OF COMPANIES & $\%(n=95)$ \\
\hline Quality control & 95 & 100.0 \\
Maintenance & 78 & 82.1 \\
\hline Different operations/machines & 71 & 74.7 \\
\hline
\end{tabular}

Source: Elaborated by the authors. 
Employee participation in terms of quality can be singled out for all the 95 companies surveyed, confirming the literature review, which points out that these activities are a major source of involvement. In addition, 78 firms stated that the workers were carrying out separate operations or operating different machines, and 7I stated that the workers were carrying out some kind of maintenance. Table 9 presents the areas in which workers were reported to perform different operations or to operate different machines. Only eight companies said that this occurs in all areas, including administration. Most companies apply versatility only in some areas, and 26 do so throughout production. In $22 \mathrm{com}$ panies, this only occurs in specific areas, such as machining and welding, mentioned by Io and 7 companies respectively. In I7 companies, there is not this kind of versatility.

\section{TABLE 9}

PRODUCTIVE AREAS AND WORKING VERSATILITY

\begin{tabular}{lcc}
\hline AREA IN WHICH VERSATILITY IS APPLIED & NUMBER OF COMPANIES & $\%(n=95)$ \\
\hline Throughout production, including assembly & 26 & 27.4 \\
\hline Specific areas of production & 22 & 23.2 \\
\hline No versatility & 17 & 17.9 \\
\hline All areas (productive and administrative) & 8 & 8,4 \\
\hline In all production and maintenance areas & 8 & 8.4 \\
\hline Assembly and some specific areas & 8 & 8.4 \\
\hline Only in assembly & 4 & 4.2 \\
\hline Not responded & 2 & 2.1 \\
\hline
\end{tabular}

Source: Elaborated by the authors.

For involvement to be possible, workers must be trained to use the methods and carry out different activities, as pointed out by Lawler et al. (1992). Thus, another research focus was the provision of training. We asked the respondents about the training offered by the company. In all, 94 different areas of training were cited in a total of $44 \mathrm{I}$ entries. Souza (2013) presents the complete list of these training area sand the number of companies citing each. In this paper, these 94 aspects of training are classified according to the areas in which they are applied, using the classification made by Araújo et al. (2006) as the 
basis. This classification is presented in Table io, together with the frequency of citation. It can be observed that most of the training is focused on quality. In second place is the training of operating technicians related to production.

\section{TABLE IO}

TRAINING CITED

\begin{tabular}{lcc}
\hline AREAS OF APPLICATION & FREQUENCY & NUMBER OF TRAINING \\
\hline Quality & 188 & 25 \\
\hline Technical/production-related operations & 108 & 23 \\
\hline Occupational health and safety & 33 & 9 \\
\hline Production management & 32 & 15 \\
\hline Other & 24 & 7 \\
\hline Project management of product & 21 & 3 \\
\hline Human resource management and motivation & 19 & 5 \\
\hline Environment & 12 & 3 \\
\hline Management of the company & 4 & 94 \\
\hline Total & 441 & 4 \\
\hline
\end{tabular}

Source: Elaborated by the authors.

Another parameter considered was the time devoted to training, as shown in Table II for companies that provided this information. It is apparent that most companies offer between one and three days of training per year.

\section{TABLE II}

DAYS OF TRAINING ANNUALLY

\begin{tabular}{lc}
\hline DAYS OF TRAINING ANNUALLY PER EMPLOYEE & NUMBER OF COMPANIES \\
\hline$<1$ day & 10 \\
\hline $1-2$ days & 12 \\
\hline $2-3$ days & 13 \\
\hline $3-4$ days & 5 \\
\hline
\end{tabular}

(continue) 


\section{TABLE II (CONCLUSION)}

\section{DAYS OF TRAINING ANNUALLY}

\begin{tabular}{lc|}
\hline DAYS OF TRAINING ANNUALLY PER EMPLOYEE & NUMBER OF COMPANIES \\
\hline $4-5$ days & 8 \\
\hline $5-6$ days & 3 \\
\hline $6-7$ days & 7 \\
\hline $7-8$ days & 3 \\
\hline$>8$ days & 8 \\
\hline Total & 69 \\
\hline
\end{tabular}

Source: Elaborated by the authors.

\section{CONCLUSIONS}

Involvement is a broad concept, studied indifferent areas and according to different aspects. For this research, we elected to study a specific and welldefined concept: the involvement of workers in the use of production management methods. This has been defined by various authors, such as Dundon et al. (2004), Faria (2009), Lawler et al. (I992), Wood and Wall (2007), and Zarifian (2009), especially in terms of collaborating with management.

The Taylor model was the target of criticism for restricting work to carrying out repetitive tasks. A model that was more advanced concerning the issue of autonomy and involvement was the socio-technical school, but this was not in widespread use. Lean production, on the other hand, has spread widely. The various manuals for lean techniques recommend the involvement of workers in their use and highlight the need for training to enable employee involvement. In addition to lean production, assorted standards and methods in the area of quality management, such as ISO 9000 and Six Sigma, also prescribe the involvement of employees.

Auto parts companies are part of the supply chain of the automotive industry, a sector relevant to the economy, to job creation, and to the development and dissemination of management methods. In recent decades, there have been changes in the purchasing behavior of automakers, who have established a new form of relationship with parts suppliers, with new requirements concerning quality in addition to the search for lower prices. In this context, auto parts 
companies have had to invest increasingly in productivity and quality. Research in this area is therefore of particular interest.

This research involved auto parts companies of different sizes and occupying different positions in the supply chain. In addition to the methods surveyed, which were deployed by the companies in the sample, another 33 methods were mentioned, among which specific standards for the automobile industry stood out. As for the year of adoption of these methods, there was only one case in the I980's, with a greater prevalence after 2000 . There is evidence suggesting that some of the respondents reported the approximate year, presumably due to lack of precise recall. This represents a limitation of using a survey for longitudinal research.

The research confirms that quality control still plays a central role with regard to the involvement of employees. This is perhaps one of the most striking legacies of lean production. Regardless of the methods used for quality control in the companies surveyed, 95 reported the involvement of employees in this area.

In addition, much of the training mentioned is dedicated to quality programs. The time devoted to training, however, was a maximum of five days per year in most companies. This helps explain the difficulty of employing methods that require a higher level of formal training, such as Six Sigma.

As in previous surveys, we also observed cases of companies that have deployed certain methods, but then ceased using them. In particular, a method with a high degree of discontinuity is the suggestion program, a method in which the involvement of employees is central. Apparently, over time, companies face problems in continuing to use suggestion programs, perhaps related to the difficulties in giving a voice to subordinates observed in surveys conducted in previous decades, such as that of Hill (I99I).

Just-in-time/Kanban also ceased to be used by many companies, but in this case, the lack of involvement of workers does not appear to be one of the reasons. The Six Sigma program, the method most recently disseminated method, showed the lowest involvement of workers, as also observed in previous research on this method. It is interesting to note that four of the five companies in this study that stopped using this method did not involve their workers in its use, reinforcing the point stressed in the manuals about the importance of employee involvement, as well as reflecting research findings in previous literature (e.g., Moriones et al., 2010; Rachid, 2009; Vidal, 2007; Wood \& Wall, 2007) showing that the involvement of employees has declined.

This research has fulfilled its goal of presenting an overview of the main adopted production management methods adopted in a large number of auto parts companies and checking for the involvement of employees in their use. Because it comprises survey research, however, it has not been possible to obtain in-depth information about the use of these methods by workers, nor to explore 
in more detail the reasons that led to firms abandoning certain methods. It would be interesting to research these aspects through more in-depth case studies, involving other actors, including the workers themselves.

\section{GESTÃO DA PRODUÇÃO E TRABALHADORES - UM SURVEY EM EMPRESAS DE AUTOPEÇAS}

\section{RESUMO}

Objetivos: Apresentar um panorama da adoção de métodos de gestão da produção por empresas de autopeças no Brasil e verificar se há o envolvimento dos trabalhadores da fábrica na sua utilização, considerando a relevância do envolvimento para o desempenho organizacional e a obtenção dos resultados esperados pela adoção desses métodos, como apontado por pesquisas sobre gestão participativa e pelos manuais da área de gestão de operações.

Originalidade/lacuna/relevância/implicações: $O$ envolvimento é um tema relevante e amplamente pesquisado, mas foram identificadas poucas pesquisas dedicadas a verificar se há o envolvimento dos trabalhadores na utilização de um conjunto mais amplo de métodos. A maior parte das pesquisas identificadas concentra sua análise na adoção de apenas um método de forma isolada, e, nelas, já se observam indícios de que as empresas nem sempre seguem as recomendações de envolver os trabalhadores em sua utilização, o que motivou a realização desta pesquisa.

Principais aspectos metodológicos: Foi realizado um survey em 95 empresas de autopeças para ter acesso a informações sobre uma grande quantidade de empresas de autopeças, traçar um panorama quanto aos métodos de gestão da produção adotados e verificar em quais há o envolvimento dos trabalhadores.

Síntese dos principais resultados: A maior parte dos métodos investigados tem sido amplamente implantada pelas empresas pesquisadas. Em sua maioria, as empresas pesquisadas responderam que há o envolvimento dos trabalhadores, embora isso varie de um método para outro. Identificaram-se casos de métodos que foram implantados e, depois de algum tempo, deixaram de ser utilizados por algumas empresas. O abandono do Seis Sigma ocorreu principalmente em empresas onde não havia o envolvimento dos trabalhadores em sua utilização. O método mais abandonado, no entanto, foi o programa de sugestões, justamente aquele em que foi apontado o maior envolvimento, o que indica que esse tipo de método ainda enfrenta dificuldades para continuar sendo utilizado ao longo do tempo em algumas empresas. O pouco tempo de treinamento também pode ter prejudicado a utilização de alguns métodos. 
Principais considerações/conclusões: Os métodos pesquisados têm sido implantados pelas empresas pesquisadas. A pesquisa confirma que a qualidade continua tendo um papel central no que diz respeito ao envolvimento dos trabalhadores, representando um dos aspectos mais marcantes da influência da produção enxuta. A maior parte dos treinamentos mencionados é voltada para essa área, mas o tempo de treinamento é curto, o que ajuda a explicar a dificuldade de envolvimento em métodos que requerem maior nível de treinamento formal. Foram observados casos de empresas que implantaram certos métodos, mas depois deixaram de usá-los, destacando-se o programa de sugestões, no qual o envolvimento dos trabalhadores é central, o que indica que persistem dificuldades relacionadas a esse envolvimento em algumas empresas.

\section{PALAVRAS-CHAVE}

Gestão da produção. Envolvimento dos trabalhadores. Métodos de gestão. Autopeças. Survey.

\section{GESTIÓN DE LA PRODUCCIÓN Y TRABAJADORES - UNA ENCUESTA EN EMPRESAS DE AUTOPARTES}

\section{RESUMEN}

Objetivos: Presentar una visión general de la adopción de métodos de gestión de la producción en empresas de autopartes en Brasil y comprobar si hay participación de los trabajadores de la fábrica en su uso, teniendo en cuenta la relevancia de la participación al desempeño de la organización y el logro de los resultados esperados por la adopción de estos métodos, como señala la investigación sobre la gestión participativa y los manuales de la área de gestión de operaciones.

Originalidad/laguna/relevancia/implicaciones: La participación es un tema relevante y ampliamente investigado, pero se han identificado pocos estudios dedicados a comprobar si existe la participación de los trabajadores en el uso de un conjunto más amplio de métodos. La mayor parte de las investigaciónes identificadas centra su análisis en la adopción de un único método de forma aislada y, en éstas, ya hay indicios de que las empresas no siempre siguen las recomendaciones de involucrar la participación de los trabajadores en su uso, lo que llevó a la realización de esta investigación.

Principales aspectos metodológicos: Se realizó una encuesta en 95 empresas de autopartes para acceder a la información sobre una gran cantidad de empresas de autopartes, dar una visión general acerca de los métodos de gestión de 
la producción adoptados y averiguar en cuáles empresas los trabajadores están implicados.

Síntesis de los principales resultados: La mayoría de los métodos investigados han sido ampliamente aplicados por las empresas encuestadas. La mayoría de las empresas encuestadas respondieron que hay implicación de los trabajadores, aunque esto varía de un método a otro. Hay casos de métodos que se han desplegado y, después de un tiempo, dejaron de utilizarse ya no se usa por algunas empresas. El abandono de Six Sigma se produjo principalmente en empresas en las que no hubo participación de los empleados en su uso. El método más abandonado, sin embargo, fue el programa de sugerencias, justamente el método en el que se señaló más implicación de los trabajadores, lo que indica que este tipo de método todavía se enfrenta a dificultades para seguir siendo utilizado a través del tiempo en algunas empresas. El poco tiempo de entrenamiento también puede haber prejudicado el uso de algunos métodos.

Principales consideraciones/conclusiones: Los métodos encuestados han sido aplicados por las empresas encuestadas. La investigación confirma que la calidad sigue teniendo un papel central en lo que respecta a la implicación de los trabajadores, lo que representa uno de los aspectos más llamativos de la influencia de la producción sobria. La mayor parte de los entrenamientos mencionada se orienta a esta área, pero el tiempo de entrenamiento es corto, lo que ayuda a explicar la dificultad de participar en los métodos que requieren un mayor nivel de capacitación formal. Se han observado casos de empresas que han implementado ciertos métodos, pero después dejaron de usarlos, destacándose el programa de sugerencias, donde la participación de los trabajadores es fundamental, lo que indica que las dificultades relacionadas con esta participación se mantienen en algunas empresas.

\section{palabras clave}

Gestión de la producción. Implicación de los trabajadores. Métodos de gestión. Autopartes. Encuesta.

\section{REFERENCES}

Alves, A. G., Filho, Rachid, A., Donadone, J. C., Martins, M. F., Bento, P. E. G., Truzzi, O. M. S., \& Vanalle, R. M. (2003). Automaker-supplier relationships and production organisation forms: case study of a Brazilian engine supply chain. International Journal of Automotive Technology and Management, 3(I-2), 6I-83.

Andrietta, J. M., \& Miguel, P. A. C. (2007). Aplicação do programa Seis Sigma no Brasil: resultados de um levantamento tipo survey exploratório-descritivo e perspectivas para pesquisas futuras. Gestão \& Produção, 14(2), 203-219. 
Araújo, Â. M. C., Gitahy, L. M. C., Rachid, A., \& Cunha, A. M. (2006). Globalização, estratégias gerenciais e respostas operárias: um estudo comparativo da indústria de linha branca (Relatório de Pesquisa), Conselho Nacional de Desenvolvimento Científico e Tecnológico, Campinas, SP.

Araújo, C. A. C., \& Rentes, A. F. (2006). A metodologia kaizen na condução de processos de mudança em sistemas de produção enxuta. Revista Gestão Industrial, 2(2), I33-I42.

Atkinson, J., \& Meager, N. (I986). Changing working patterns: how companies achieve flexibility to meet new needs. London: Institute of Manpower Studies, National Economic Development Office.

Batt, R., \& Doellgast, V. (2004). Groups, teams and the division of labor: interdisciplinary perspectives on the organization of work. In A. Stephen, B. Rosemary, T. Paul \& S. T. Pamela (Orgs.). The Oxford handbook of work and organization (pp. I38-I6r). London: Oxford.

Butler, P. A., Tregaskis, O., \& Glover, L. A. (20II, November). Workplace partnership and employee involvement - contradictions and synergies: evidence from a heavy engineering case study. Economic and Industrial Democracy, 34(I), 5-24.

Carvalho, R. Q., Queiroz, S. R. R., Consoni, F. L., Costa, I., \& Costa, J. O. P. (I997). Abertura comercial e mudança estrutural na indústria automobilística brasileira (Relatório de Pesquisa), Campinas, SP, Universidade Estadual de Campinas.

Cheng, J.-L. (2007). Comparative study of local and transnational enterprises in Taiwan and their implementation of Six Sigma. Total Quality Management, 18(7), 793-806.

Cherns, A. (1976). The principles of sociotechnical design. Human Relations, 29(8), 783-792.

Coriat, B. (1985). O Taylorismo e a expropriação do saber operário. In D. Pimentel, F. Costa e Silva, J. Freire, K. Wall \& M. P. Lima. Sociologia do trabalho: organização do trabalho industrial - Antologia (pp. 8I-I07). Lisboa: A Regra do Jogo.

Coriat, B. (I988). Automação programável: novas formas e conceitos de organização da produção. In S. Hubert \& Q. C. Ruy (Orgs.). Automação, competitividade e trabalho: a experiência internacional (pp. 13-6I). São Paulo: Hucitec.

Costa, I. (1998). O setor de autopeças no Brasil: desafios e mudanças na década de noventa. Campinas. Dissertação de mestrado, Universidade Estadual de Campinas, Campinas, SP, Brasil.

Dias, A. V., \& Zilbovicius, M. (2009). Trabalho e criação de valor: financeirização da produção e novas formas de organização do trabalho. In A. P. C. Mondadore, A. J. Pedroso Neto, E. S. Leite, M. A. C. Jardim \& M. S. Sartore. Sociologia econômica e das finanças: um projeto em construção (pp. II9-I32). São Carlos: Editora da UFSCar.

Donadone, J. C., \& Grün, R. (200I). Participar é preciso! Mas de que maneira? Revista Brasileira de Ciências Sociais, 16(47), III-I83.

Dundon, T., Wilkinson, A., Marchington, M., \& Ackers, P. (2004, September). The meanings and purpose of employee voice. International Journal of Human Resource Management, 15(6), II49-II70. Edwards, P., Geary, J., \& Sisson, K. (2002). New forms of work organization in the workplace: transformative, exploitative, or limited and controlled? (pp. 72-II9). In M. Gregor, B. Jacques, G. Anthony \& A. L. Paul (Eds.). Work and employment relations in the high performance workplace (pp. 72-II9). London: Continuum.

Faria, J. H. (2009). Gestão participativa: relações de poder e trabalho nas organizações. São Paulo: Atlas. Felstead, A., Gallie, D., Green, F., \& Zhou, Y. (20I0). Employee involvement, the quality of training and the learning environment: an individual level analysis. The International Journal of Human Resource Management, 21(10), I667-1688. 
Ferreira, C. G., Hirata, H., Marx, R., \& Salerno, M. S. (I99I). Alternativas sueca, italiana e japonesa ao paradigma fordista: elementos para uma discussão sobre o caso brasileiro. Cadernos do Cesit, 4, I-3o. Ferro. J. R. (20IIa). As dificuldades do sistema puxado. Lean M@il, boletim mensal, abr. Retrieved March, 20I6, from http://www.lean.org.br/colunas/387/as-dificuldades-do-sistema-puxado.aspx. Ferro. J. R. (20IIb). As dificuldades do sistema puxado. Lean M@il, boletim mensal, June. Retrieved March, 20I6, from http://www.lean.org.br/colunas/389/dificuldades-para-a-implementacao-do-sistema-puxado-comentarios-da-comunidade-lean.aspx.

Fleury, A. C. C., \& Humphrey, J. (I992). Recursos humanos e a difusão de novos métodos para a qualidade no Brasil (Relatório de Pesquisa). Brasília, DF: Instituto de Pesquisa Aplicada.

Ford, H. (I925). Minha vida e minha obra (Em colaboração com Samuel Crowther; S. Bueno, Trad.). São Paulo: Monteiro Lobato.

Friedrich, A., Kabst, R., Weber, W., \& Rodehuth, M. (I998). Functional flexibility: merely reacting or acting strategically? Employee Relations, 20(5), 504-523.

Fulton, R. (2003). Paying for Six Sigma. Workforce, 82(I), 56-58.

Gerwin, D. (I987). An agenda for research on the flexibility of manufacturing processes. International Journal of Operations \& Production Management, 7(I), 38-49.

Gonzalez, M. C. (20I0). Workers' direct participation at the workplace and job quality in Europe. Journal of European Social Policy, 20(2), I60-168.

Heller, F. (I998). Playing the devil's advocate: limits to influence sharing in theory and practice. In F. Heller, E. Pusic, G. Strauss \& B. Wilpert. Organizational participation: myth and reality (pp. I44-I89). Oxford: Oxford University Press.

Heller, F. (2003). Participation and power: a critical assessment. Applied Psychology: An International Review, 52(I), I44-I63.

Helper, S., \& Kleiner, M. M. (2008). International differences in lean production, productivity and employee attitudes. In B. F. Richard \& L. S. Kathryn (Eds.). International differences in the business practices and productivity of firms (pp. 407-473). Chicago: University of Chicago Press, NBER.

Hill, S. (I99I). Why quality circles failed but Total Quality might succeed. British Journal of Industrial Relations, 29(4), 54I-568.

Invernizzi, N. (2000). Qualificação e novas formas de controle da força de trabalho no processo de reestruturação da indústria brasileira: tendências dos últimos vinte anos. Anais do Encontro da Associação Nacional de Pós-Graduação e Pesquisa em Educação (Anped), Caxambu, MG, Brasil, 23. Iwaarden, J. V., Wielea, T. V., Daleb, B., Williams A, R., \& Bertsch, B. (2008). The Six Sigma improvement approach: a transnational comparison. International Journal of Production Research, 46(23), 6739-6758.

Jones, D. C., Kalmi, P., \& Kauhanen, A. (2010). How does employee involvement stack up? The effects of human resource management policies on performance in a retail firm. Industrial Relations, 49(I), I-2I. DOI: IO.IIII/j.I468-232X.2009.00584.X.

Kalleberg, A. L., Nesheim, T., \& Olsen, K. M. (2009). Is participation good or bad for workers? Effects of autonomy, consultation and teamwork on stress among workers in Norway. Acta Sociologica, 52(2), 99-II6.

Larangeira, S. M. G. (I997). Fordismo e pós-fordismo. (p. 89-94). In D. C. Antonio (Org.). Trabalho e tecnologia: dicionário crítico (pp. 89-94). Petrópolis: Vozes. 
Lawler, E. E. (I986). High-involvement management. San Francisco: Jossey-Bass.

Lawler, E. E., Mohrman, S. A., \& Ledford, G. (1992). Employee involvement and Total Quality management: practices and results in Fortune Ioo० Companies. San Francisco: Jossey-Bass.

Liboni, M. T. L. (200I). A história da participação dos trabalhadores nas empresas: uma revisão crítica. Anais do Encontro Anual da Associação Nacional dos Programas de Pós-Graduação em Administração, Campinas, SP, Brasil, 25.

Marx, R. (I997). Trabalho em grupos e autonomia como instrumentos da competição. São Paulo: Atlas. Moriones, A. B., Pintado, A. P. B., \& Merino, J. D. D. C. (2010). The effects of integrated manufacturing on job characteristics. New Technology, Work and Employment, 25(I), 63-79.

Nichols, T., \& Cam, S. (Orgs.). (2005). Labour in a global world: the case of white goods. London: Palgrave Macmillan.

Ogbeide, G.-C. A., \& Harrington, R. J. (20II). The relationship among participative management style, strategy implementation success, and financial performance in the food service industry. International Journal of Contemporary Hospitality Management, 23(6), 719-738.

Olivella, J., Cuatrecasas, L., \& Gavilan, N. (2008). Work organisation practices for lean production. Journal of Manufacturing Technology Management, 19(7), 798-8II.

Perticarrari, D. (2003). Reestruturação produtiva e emprego na indústria da linha branca no Brasil. Dissertação de mestrado, Universidade Estadual de Campinas, Campinas, SP, Brasil.

Pinto, S. H. B., Carvalho, M. M., \& Ho, L. L. (2009). Programa Seis Sigma: aspectos sinérgicos com outras abordagens de gerenciamento da qualidade. Revista Produção Online, 9(I), 70-I93.

Ponticel, P. (2004). Ford still riding Six Sigma quality horse. Automotive Engineering International, 12(4), 67.

Pyzdek, T. (2003, maio-junho). Uma ferramenta em busca do defeito zero. HSM Management, 38(3), I-7.

Quazi, H. A., \& Jacobs, R. L (2004). Impact of ISO 9000 certification on training and development activities. International Journal of Quality \& Reliability Management, 21(5), 497-5I7.

Rachid, A. (I996). O Brasil imita o Japão? A qualidade em empresas de autopeças. Cadernos de Gestão Tecnológica, 32, I-67. Retrieved 28 March, 2016, from http://www.fundacaofia.com.br/pgtusp/ publicacoes/arquivos_cyted/cad32.pdf.

Rachid, A. (2007, março). Estratégias gerenciais e flexibilidade do trabalho (Relatório de Pesquisa/2007), São Paulo, SP, Fundação de Amparo à Pesquisa do Estado de São Paulo.

Rachid, A. (2009). Contribuição dos trabalhadores para a gestão da produção na indústria de eletrodomésticos. Anais do Simpósio de Administração da Produção, Logística e Operações Internacionais (Simpoi), São Paulo, SP, Brasil, I2.

Rachid, A., Bresciani, F. E., \& Gitahy, L. C. (200I, dezembro). Relações entre grandes e pequenas empresas de autopeças e a difusão de práticas de gestão da produção. Gestão \& Produção, 8(3), 319-333. Rachid, A., Sacomano, M., Neto, Bento, P. E. G., Donadone, J. C., \& Alves, A. G., Filho (2006). Organização do trabalho na cadeia de suprimentos: os casos de uma planta modular e de uma tradicional na indústria automobilística. Produção, 16(2), I89-202.

Richardson, M., Danford, A., Stewart, P., \& Pulignano, V. (2010). Employee participation and involvement: experiences of aerospace and automobile workers in the UK and Italy. European Journal of Industrial Relations, 16(I), 2I-37. 
Salerno, M. S. (1985). Produção e participação: CCQ e Kanban numa nova imigração japonesa. In M. T. Fleury \& Rosa F. (Eds.). Processo e relações de trabalho no Brasil (pp. I79-20I). São Paulo: Atlas. Salerno, M., Zilbovicius, M., Arbix, G., \& Dias, A. V. C. (I998). Mudanças e persistências no padrão de relações entre montadoras e autopeças no Brasil. Revista de Administração, 33(3), 68-28. Santos, A. M. M. M., \& Pinhão, C. M. A. (2000, março). Panorama geral do setor de autopeças. BNDES Setorial, (II), 7I-86.

Schroeder, R. G., Linderman, K., Liedtke, C., \& Choo, A. S. (2008). Six Sigma: definition and underlying theory. Journal of Operations Management, 26(4), 536-554.

Sindicato Nacional da Indústria de Componentes para Veículos Automotores (20II). Anuário Sindipeças. São Paulo: Sindipeças.

Sindicato Nacional da Indústria de Componentes para Veículos Automotores. (20I2). Anuário Sindipeças. São Paulo: Sindipeças.

Sindicato Nacional da Indústria de Componentes para Veículos Automotores (20I4). Anuário Sindipeças. São Paulo: Sindipeças.

Slack, N., Chambers, S., \& Johnston, R. (2002). Administração da produção (2a ed.). São Paulo: Atlas. Smith, B. (2003, April). Lean and Six Sigma - a one-two punch. Quality Progress, 36(4), 37-4I.

Smith, V. (1997). New forms of work organization. Annual Review of Sociology, 23, 3I5-339.

Smith, V. (2006). Worker participation: current research and future trends. Research in the Sociology of Work, 16, xi-xxiii.

Souza, L. C. (20I3). Envolvimento dos trabalhadores na gestão da produção e da qualidade na indústria de autopeças. Dissertação de mestrado, Universidade Federal de São Carlos, São Carlos, SP, Brasil. Souza, L. C., Rachid, A. (20I4). Internationalization and Geographical Relocation of Brazil's AutoParts Industry. Brazilian Journal of Operations and Production Management, 10(2), 23-32.

Tang, Z., Chen, X., \& Wu, Z. (20IO, December). Using behavior theory to investigate individuallevel determinants of employee involvement in TQM. Total Quality Management, 21(I2), I23I-I260. Vidal, M. (2007). Manufacturing empowerment? "Employee involvement" in the labour process after Fordism. Socio-Economic Review, 5(2), 197-232.

Wilkinson, A., Donaghey, J., Dundon, T., \& Freeman, R. B. (Orgs.). (20I4). Handbook of research on employee voice. Northampton, MA: Elgar.

Womack, J. P., Jones, D. T., \& Roos, D. (I992). A máquina que mudou o mundo. Rio de Janeiro: Campus.

Wood, S. (1989). The transformation of work? In W. Stephen (Org.). The transformation of work? Skill, flexibility and the labour process (pp. I-43). Boston: Unwin Hyman.

Wood, S. J., \& Wall, T. D. (2007). Work enrichment and employee voice in human resource management-performance studies. The International Journal of Human Resource Management, 18(7), I335-1372.

Zarifian, P. (2009). Uma crise inédita do capitalismo, tanto em suas características como em sua gravidade: análise e perspectivas. Revista Estudos Avançados, 23(65), 7-26.

$\mathrm{Zu}, \mathrm{X}$., Robbins, T. L., \& Fredendall, L. D. (2010). Mapping the critical links between organizational culture and TQM/Six Sigma practices. International Journal of Production Economics, 123(I), 86-1o6. 


\section{APPENDIX A}

TABLE I

ADOPTION OF METHODS OF PRODUCTION MANAGEMENT IN THE SURVEYED COMPANIES

\begin{tabular}{|c|c|c|c|}
\hline METHOD & ADOPTED & METHOD & ADOPTED \\
\hline Preventive maintenance & 86 & DOT & 1 \\
\hline Troubleshooting groups & 80 & Ford Q1 & 1 \\
\hline ISO 9000 & 80 & Gap analysis & 1 \\
\hline Suggestion programs & 76 & Management view & 1 \\
\hline ISO TS16949 & 63 & IEC 17025 & 1 \\
\hline Just-in-time/Kanban & 60 & KPI & 1 \\
\hline ISO 14000 & 48 & MMOG - Ford & 1 \\
\hline Total Quality & 45 & SA 8000 & 1 \\
\hline Six Sigma & 26 & Customer standards & 1 \\
\hline QSB & 14 & PDCA & 1 \\
\hline VDA & 10 & Pokayoke & 1 \\
\hline Lean Manufacturing & 7 & QFD & 1 \\
\hline OHSAS 18001 & 6 & Quality/Business operating system & 1 \\
\hline $5 S$ & 5 & Quick Response Quality Control & 1 \\
\hline QS9000 & 5 & Renault ASES & 1 \\
\hline Kaizen & 4 & Shainin & 1 \\
\hline $8 \mathrm{D}$ & 2 & OhnoSystem of Manufacture & 1 \\
\hline BSC & 2 & Toyota System of Production & 1 \\
\hline Fiev - PSA & 2 & Continuous improvement systems & 1 \\
\hline MRP ॥ & 2 & WCM & 1 \\
\hline Design For Six Sigma & 1 & & \\
\hline
\end{tabular}

Source: Elaborated by the authors. 